\title{
The Relationship between the Pacific-North American Teleconnection Pattern, the Great Plains Low-Level Jet, and North Central U.S. Heavy Rainfall Events*
}

\author{
Keith J. HARding AND Peter K. SNYder \\ Department of Soil, Water, and Climate, University of Minnesota, St. Paul, Minnesota
}

(Manuscript received 25 September 2014, in final form 7 May 2015)

\begin{abstract}
This study demonstrates the relationship between the Pacific-North American (PNA) teleconnection pattern and the Great Plains low-level jet (GPLLJ). The negative phase of the PNA, which is associated with lower heights over the Great Plains and ridging in the southeastern United States, enhances the GPLLJ by increasing the pressure gradient within the GPLLJ on 6-hourly to monthly time scales. Strong GPLLJ events predominantly occur when the PNA is negative. Warm-season strong GPLLJ events with a very negative PNA $(<-1)$ are associated with more persistent, longer wavelength planetary waves that increase the duration of GPLLJ events and enhance precipitation over the north central United States. When one considers the greatest 5-day north central U.S. precipitation events, a large majority occur when the PNA is negative, with most exhibiting a very negative PNA. Stronger moisture transport during heavy rainfall events with a very negative PNA decreases the precipitation of locally derived moisture compared to events with a very positive PNA. The PNA becomes negative 2-12 days before heavy rainfall events and is very negative within two weeks of $78 \%$ of heavy rainfall events in the north central United States, a finding that could be used to improve medium-range forecasts of heavy rainfall events.
\end{abstract}

\section{Introduction}

Heavy rain events and associated flash flooding routinely cause significant economic losses in the midwestern United States and are the leading cause of weather-related deaths (NWS 2014). Because of their large societal impacts, considerable effort has been spent on improving medium-range (3-14 day) prediction of heavy rainfall events and their drivers, such as the Great Plains low-level jet (GPLLJ) and atmospheric rivers (Nayak et al. 2014). Recent research has identified that the Pacific-North American (PNA) teleconnection pattern, which has significant variability within the medium-range forecasting window (Feldstein 2000), may have influenced the development of two heavy

\footnotetext{
* Supplemental information related to this paper is available at the Journals Online website: http://dx.doi.org/10.1175/JCLI-D-1400657.s1.

Corresponding author address: Peter K. Snyder, Department of Soil, Water, and Climate, 439 Borlaug Hall, 1991 Upper Buford Circle, Saint Paul, MN 55108.

E-mail: pksnyder@umn.edu
}

rainfall events with flash flooding over the Midwest by enhancing the GPLLJ (Patricola et al. 2015). In this study, we examine the impact that the PNA has on the GPLLJ on monthly time scales as well as how the PNA impacts strong jet events and north central U.S. heavy rainfall events at daily to pentadal (5 day) time scales.

The GPLLJ, a southerly lower-tropospheric wind maximum that is a key feature of the midwestern summertime hydroclimate, is the primary driver of summertime nocturnal convective precipitation in the central United States (Higgins et al. 1997; Means 1954). Low-level convergence, cyclonic shear, and moisture convergence to the north of the GPLLJ maximum (Bonner 1968; Helfand and Schubert 1995; Weaver and Nigam 2011) support the development of nocturnal mesoscale convective systems (MCSs), which are responsible for a significant percentage of total summer rainfall in the region (Higgins et al. 1997). In the midwestern United States, heavy rainfall events peak in the summer months (Dirmeyer and Kinter 2010) and are often associated with anomalously strong meridional moisture transport (i.e., atmospheric rivers) within the GPLLJ (Arritt et al. 1997; Cook et al. 2008; Lavers and Villarini 2013; Monaghan et al. 2010). 
The GPLLJ typically is the strongest during July and is located between 925 and $850 \mathrm{hPa}$ (Cook et al. 2008). Variations in the GPLLJ are influenced by fluctuations in the 850-hPa height gradient between the North Atlantic subtropical high (NASH) and lower heights over the Great Plains and the front range of the Rocky Mountains (Holton 1967), with stronger wind speeds at night due to the decoupling of the surface and boundary layers. Anomalous low-level ridging on the western edge of the NASH (Weaver et al. 2009b) or an enhanced 850-hPa trough over the Great Plains (Mo and Berbery 2004; Weaver and Nigam 2008) can strengthen the GPLLJ by enhancing the pressure gradient across the GPLLJ core (Holton 1967).

The PNA teleconnection pattern is a prominent mode in Northern Hemisphere low-frequency variability (Wallace and Gutzler 1981) that is more pronounced during the winter (Barnston and Livezey 1987). However, the PNA exerts significant variability on daily to weekly time scales (Feldstein 2000) and can influence weather patterns over the Midwest during the summer months (Patricola et al. 2015). Previous studies have linked the PNA teleconnection pattern to diabatic heating anomalies associated with convection in the North Pacific (Yu et al. 2009), ENSO-related tropical convection (Trenberth et al. 1998), and variations in the East Asian jet (Lau and Boyle 1987; Leathers and Palecki 1992). Weaver and Nigam (2008) showed that PNA-initiated Rossby waves associated with convection in the tropical North Pacific are responsible for generating a specific pattern expressed in $200-\mathrm{hPa}$ heights that ultimately affects 850 -hPa height gradients and the GPLLJ in July. This suggests that precipitation, and associated diabatic heating anomalies, over the Pacific may play a role in affecting the strength of the GPLLJ. The negative phase of the PNA, which results in upper-level troughing over western North America and ridging over the southeastern United States, has been previously linked to two summer heavy rainfall events in the Midwest (Patricola et al. 2015).

In this study, we demonstrate how the PNA impacts the GPLLJ and north central U.S. precipitation on monthly time scales using the NCEP-NCAR reanalysis. After establishing the mechanisms linking the PNA and the GPLLJ, we investigate how the PNA influences the GPLLJ and extreme rainfall events on time scales associated with synoptic weather systems ( $\leq 5$ days). Ultimately, the goal of this study is to improve mediumrange weather prediction of extreme precipitation events in the upper Midwest.

\section{Methods}

\section{a. Data}

The NCEP-NCAR reanalysis (Kalnay et al. 1996), which is available every $6 \mathrm{~h}$ on a $2.5^{\circ} \times 2.5^{\circ}$ global grid starting in 1948, was used for all analyses except those that included precipitation over the contiguous United States (CONUS). For precipitation, the Climatic Research Unit's (CRU) monthly precipitation dataset (Harris et al. 2014) was used for monthly analyses of precipitation over land and the Climate Prediction Center's (CPC) daily precipitation dataset (Higgins et al. 2000), available starting in 1948 at $0.25^{\circ} \times 0.25^{\circ}$ over CONUS, was used for all daily and 5-day precipitation. Monthly precipitation from the NCEPNCAR reanalysis was used over the oceans where the other precipitation datasets are not available.

\section{b. PNA calculation}

All PNA values were calculated using the modified pointwise method from the Climate Prediction Center (CPC 2014), which defines the PNA as

$$
\begin{aligned}
\mathrm{PNA}= & Z^{*}\left(15^{\circ}-25^{\circ} \mathrm{N}, 180^{\circ}-140^{\circ} \mathrm{W}\right)-Z^{*}\left(40^{\circ}-50^{\circ} \mathrm{N}, 180^{\circ}-140^{\circ} \mathrm{W}\right) \\
& +Z^{*}\left(45^{\circ}-60^{\circ} \mathrm{N}, 125^{\circ}-105^{\circ} \mathrm{W}\right)-Z^{*}\left(25^{\circ}-35^{\circ} \mathrm{N}, 90^{\circ}-70^{\circ} \mathrm{W}\right),
\end{aligned}
$$

where $Z^{*}$ is the mean $500-\mathrm{hPa}$ geopotential height anomaly from NCEP-NCAR compared to the 19812010 average. Calculations using the modified pointwise method are highly correlated with the original pointwise method from Wallace and Gutzler (1981) $(R=0.98)$ and those using an EOF analysis $(R=0.92)$ (CPC 2014). Daily PNA values were standardized by 1981-2010 daily means and standard deviations after a 1-1-1-1-2-2-2-2-1-1-1-1 filter was applied four times to the climatological mean and standard deviation of the PNA from Eq. (1) to reduce the noise of the daily data, similar to the approach that Weaver et al. (2009a) used on pentad data (a 1-2-1 filter applied four times). Monthly values were standardized by the 1981-2010 average of all months to enable an examination of the annual cycle of the PNA on the GPLLJ. Daily PNA values at least one standard deviation below average (PNA $<-1$ ) were classified as "very negative" and corresponding positive values (PNA > 1) were termed "very positive." 




FIG. 1. The north central U.S. region (NCUS; $40^{\circ}-50^{\circ} \mathrm{N}, 102.5^{\circ}-$ $\left.87.5^{\circ} \mathrm{W}\right)$, the Great Plains region $\left(\mathrm{GP} ; 35^{\circ}-50^{\circ} \mathrm{N}, 110^{\circ}-100^{\circ} \mathrm{W}\right)$, the southeastern U.S. region (SEUS; $25^{\circ}-40^{\circ} \mathrm{N}, 95^{\circ}-80^{\circ} \mathrm{W}$ ), and the LLJ region $\left(27.5^{\circ}-42.5^{\circ} \mathrm{N}, 102.5^{\circ}-90^{\circ} \mathrm{W}\right)$ used in this study.

\section{c. Definition of precipitation extremes}

Extreme precipitation events in this study were analyzed using individual grid cell maxima rather than regional averages because the impacts from localized heavy rainfall events are likely much larger than those from regional averages. The heaviest 1- and 5-day rainfall events over the north central United States were determined by calculating the highest grid cell rainfall totals during the warm season (April-October) in the CPC dataset and eliminating duplicates. When multiple overlapping 5-day periods had the same rainfall total, the event was centered on the day with the most daily precipitation.

\section{d. Definition of other indices}

The low-level jet (LLJ) index is the average $850-\mathrm{hPa}$ meridional wind speed within the LLJ region $\left(27.5^{\circ}-\right.$ $42.5^{\circ} \mathrm{N}, 102.5^{\circ}-90^{\circ} \mathrm{W}$; Fig. 1), which overlaps the climatological maximum of the GPLLJ. To represent the geopotential height gradient that modulates the speed of the GPLLJ, we define the Zgrad index, which is the average $850-\mathrm{hPa}$ geopotential height in the southeastern United States (SEUS; $25^{\circ}-40^{\circ} \mathrm{N}, 95^{\circ}-80^{\circ} \mathrm{W}$; Fig. 1) on the western edge of the NASH minus the average $850-\mathrm{hPa}$ heights in the Great Plains region (GP; $35^{\circ}-$ $50^{\circ} \mathrm{N}, 110^{\circ}-100^{\circ} \mathrm{W}$; Fig. 1). The Zgrad index was standardized by the 1981-2010 average and standard deviation. Both indices were calculated on monthly, pentadal (5 day), daily, and 6-hourly time scales. The inclusion of 6-hourly data allows an examination of how the PNA affects LLJ events, which are highly influenced by the diurnal nature of the GPLLJ and are less apparent in daily averages.

\section{e. LLJ categories and strong LLJ event classification}

Times with an active LLJ were determined using 6-hourly 850-hPa winds, following criteria from Arritt et al. (1997). Weak LLJs were defined whenever the maximum wind speed within the LLJ region was between 12 and $16 \mathrm{~m} \mathrm{~s}^{-1}$, with ranges of $16-20 \mathrm{~m} \mathrm{~s}^{-1}$ for moderate LLJs and over $20 \mathrm{~m} \mathrm{~s}^{-1}$ for strong LLJs. The identification of LLJs only considered wind directions between $135^{\circ}$ and $225^{\circ}$. We classified strong LLJ events as discrete periods of time with a strong LLJ. If multiple strong LLJs occurred within $12 \mathrm{~h}$, they were classified as the same strong LLJ event. The average daily PNA index during strong LLJ events was calculated to enable the grouping of multiple LLJ events with the same PNA classification (e.g., very negative, negative, positive, and very positive).

\section{f. Precipitation recycling ratio calculation}

For the top 100 5-day rainfall events in the north central United States from the CPC dataset (defined in section 2c), precipitation recycling ratios were calculated using daily precipitation data from CPC and daily temperature, winds, latent heat flux, and moisture from the NCEP-NCAR reanalysis. All recycling ratio calculations used the quasi-isentropic back-trajectory technique (QIBT) from Brubaker et al. (2001). One hundred parcels were launched for each grid cell within the north central United States during each 5-day rainfall event, with each parcel representing 1/100th of the total pentad precipitation within a grid cell. Parcels were launched at the occurrence of precipitation and the horizontal and vertical location of parcel launches was randomized, with the height of launches weighted by the vertical profile of tropospheric moisture. After parcels were launched, the evaporative source of precipitation was determined by dividing the evapotranspiration for each time step $(4 \mathrm{~h})$ by the total column precipitable water. Parcels were tracked backward using the iterative backward trajectory technique from Merrill et al. (1986) every $4 \mathrm{~h}$ (interpolated linearly from daily data) for up to 21 days or until all the moisture was accounted for. Recycling ratios were determined by dividing the total north central U.S. precipitation by the amount of precipitation that was locally derived. Recycling ratios were calculated for the north central region, which is approximately $1.31 \times 10^{6} \mathrm{~km}^{2}$, slightly larger than the area of $1.0 \times 10^{6} \mathrm{~km}^{2}$ that is recommended to capture mesoscale and synoptic moisture transport while also capturing small-scale variability (Dominguez et al. 2006; Rasmusson 1968).

\section{Impact of the PNA on the GPLLJ at monthly time scales}

To examine how the GPLLJ is affected by the PNA at monthly time scales, we consider the difference in 
TABLE 1. Average and standard deviation of LLJ index, north central U.S. precipitation (from CRU), and the PNA index (unstandardized; units of meters) for April-October and November-March from NCEP-NCAR.

\begin{tabular}{|c|c|c|c|c|}
\hline \multirow[b]{2}{*}{ Variable } & \multicolumn{2}{|c|}{ April-October } & \multicolumn{2}{|c|}{ November-March } \\
\hline & Avg & Std dev & Avg & Std dev \\
\hline LLJ index $\left(\mathrm{m} \mathrm{s}^{-1}\right)$ & 2.93 & 0.44 & 0.71 & 0.87 \\
\hline NCUS precipitation $\left(\mathrm{mm}\right.$ month $\left.{ }^{-1}\right)$ & 74.04 & 10.28 & 26.10 & 9.05 \\
\hline PNA index (m; unstandardized) & 0 & 1.64 & 0 & 2.65 \\
\hline
\end{tabular}

geopotential heights, column-integrated precipitable water, precipitation, and meridional winds between the 10 strongest and weakest LLJ years for all months. This analysis was also conducted for all warm season months (April-October) and all cold season months (November-March). Differences between the strongest and weakest LLJ months were calculated by grouping composites of the 10 strongest and weakest LLJ years for each calendar month and then averaging across all the strongest and weakest LLJ months (a set of 120 total months for each group). Averages were computed in the same way for the warm season (April-October) when the GPLLJ is less variable (Table 1) but has a much larger impact on precipitation in the north central United States (NCUS) (Table 2). Cold season months (November-March) were also averaged in this manner.

For all months, strong $850-\mathrm{hPa}$ southerly flow in the central United States during strong LLJ months (Fig. 2a) contributes to enhanced column-integrated moisture transport in the southern plains (Fig. 2b). During the warm season, the LLJ has less variability (Table 1) and the difference in southerly low-level flow for strong minus weak LLJ months is slightly smaller (Fig. 2f; Table 2). However, much larger increases in moisture transport occur in strong LLJ months during the warm season (Fig. 2g) compared to averages for all months (Fig. 2b) and cold season months (see Fig. S1 in the supplemental material). Greater meridional transport of moisture during strong LLJ years throughout the southern plains and lower Mississippi valley increases precipitation over much of the central United States when considering all months and just warm season months (Figs. 2c,h). Because of large increases in moisture transport during strong LLJ months in the warm season, the precipitation response associated with strong LLJ months is much greater during the warm season than the cold season (Figs. 2c,h and 3a,e, Table 2; see Fig. S1).

Considering averages over all months, enhanced southerly flow during strong LLJ months is coincident with higher $850-\mathrm{hPa}$ geopotential heights over the southeastern United States and troughing over the mountain west and Great Plains (Fig. 2d), as the stronger height gradient enhances meridional flow within the GPLLJ core. Slightly weaker height anomalies are present when considering just warm season months (Fig. 2i), likely explaining the smaller increase in LLJ speeds during the strong LLJ months in the warm season compared with all months. Height differences between the Great Plains and southeastern U.S. regions at $850 \mathrm{hPa}$ (Zgrad index) are responsible for $90 \%$ of the variance in the LLJ index when considering all months (Fig. 4a), with a similar relationship during the warm season (91\%; Fig. 4d) and the highest correlation in April (95\% of the variance explained). Differences in geopotential heights at $500 \mathrm{hPa}$ for all months (Fig. 2e) are collocated with 850-hPa height differences (Fig. 2d), with a slight westward shift (negative tilt) with height. Height differences at $500 \mathrm{hPa}$ are in nearly the same locations during the warm season but have a slightly weaker magnitude than averages for all months (Fig. 2j), as evidenced by the smaller difference in the unstandardized PNA index during the warm season (Table 1). Similar geopotential height differences between strong and weak LLJ years at 500 and $850 \mathrm{hPa}$ (Figs. $2 \mathrm{~d}, \mathrm{e}, \mathrm{i}, \mathrm{j})$ reveal a height pattern that resembles differences between the most negative minus most positive

TABLE 2. Monthly PNA index, LLJ index, and NCUS precipitation during 10 wettest and driest years in NCUS as well as 10 strongest LLJ years and 10 weakest LLJ years (lowest average $850 \mathrm{hPa}$ meridional wind in LLJ region), averaged across months of April-October and November-March.

\begin{tabular}{|c|c|c|c|c|c|c|}
\hline \multirow[b]{2}{*}{ Variable } & \multicolumn{3}{|c|}{ April-October } & \multicolumn{3}{|c|}{ November-March } \\
\hline & PNA & LLJ index $\left(\mathrm{m} \mathrm{s}^{-1}\right)$ & $\begin{array}{l}\text { Precipitation } \\
\left(\mathrm{mm} \text { month }^{-1}\right)\end{array}$ & PNA & LLJ index $\left(\mathrm{m} \mathrm{s}^{-1}\right)$ & $\begin{array}{l}\text { Precipitation } \\
\left(\mathrm{mm} \text { month }^{-1}\right)\end{array}$ \\
\hline 10 wettest & -0.65 & 4.00 & 113.56 & -0.34 & 1.75 & 42.62 \\
\hline 10 driest & 0.73 & 1.87 & 41.26 & 0.40 & -0.48 & 11.64 \\
\hline 10 strongest LLJ & -0.94 & 4.69 & 96.58 & -1.09 & 3.01 & 33.41 \\
\hline 10 weakest LLJ & 0.86 & 1.33 & 53.97 & 1.01 & -1.56 & 16.31 \\
\hline
\end{tabular}



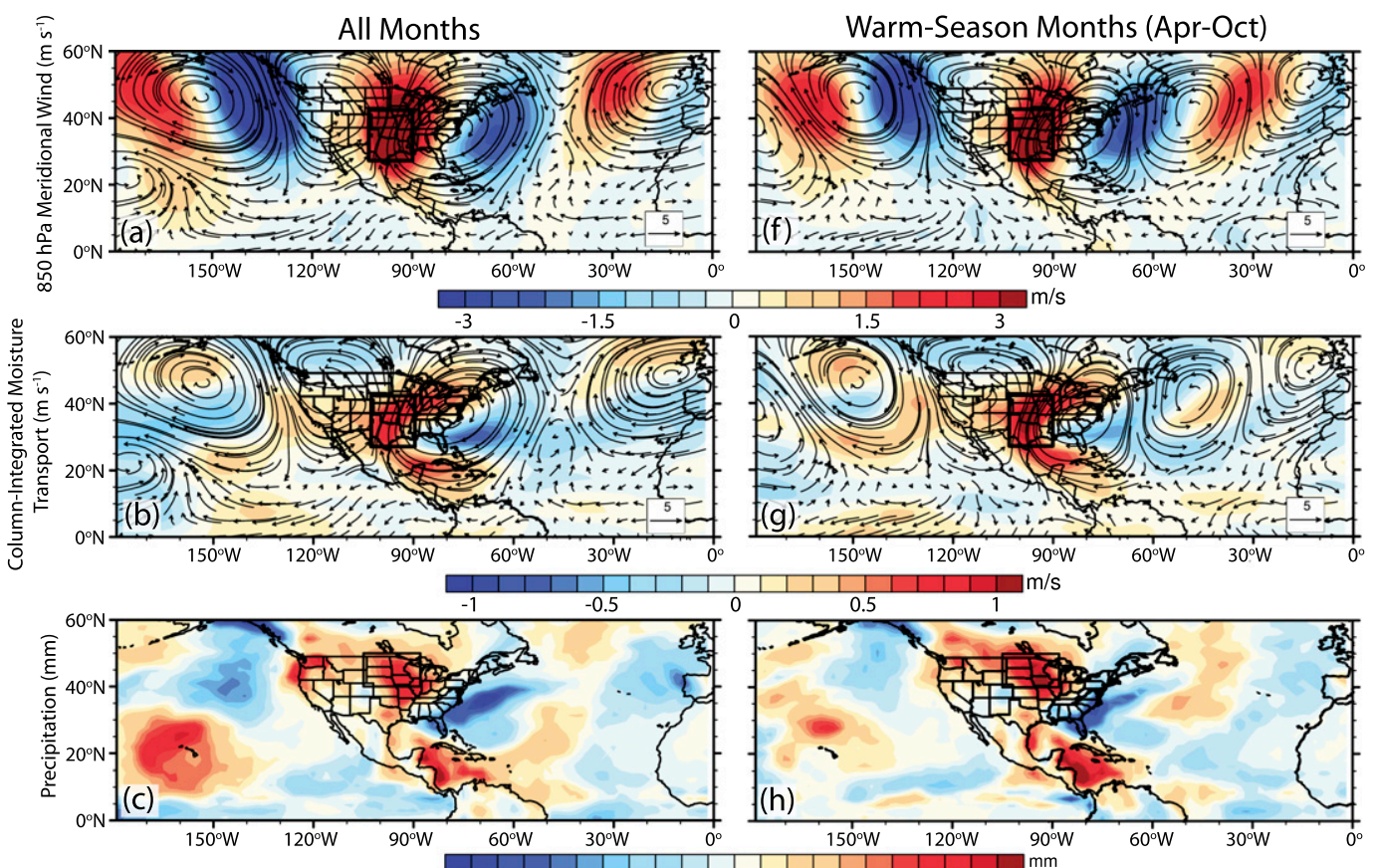

$-50$
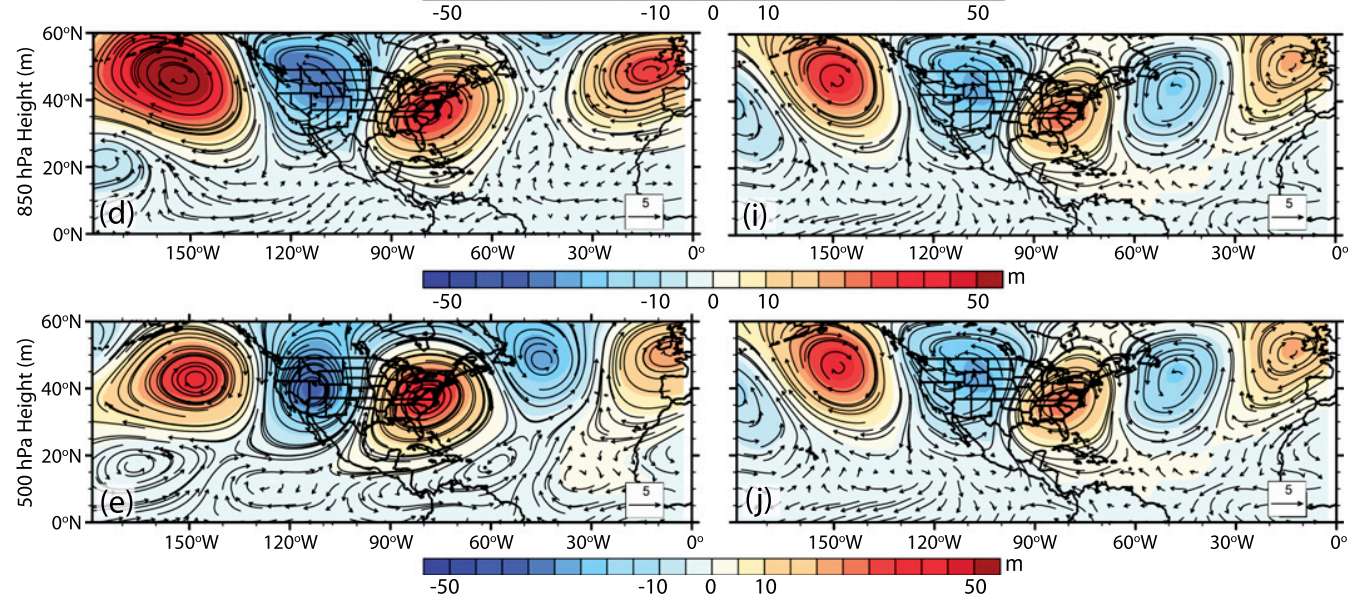

FIG. 2. The average over all calendar months during the 10 strongest minus 10 weakest LLJ years over the 19482013 period from NCEP-NCAR in (a) 850-hPa meridional wind and $850-\mathrm{hPa}$ wind vectors ( $\mathrm{m} \mathrm{s}^{-1}$ ), (b) columnintegrated moisture transport and $850-\mathrm{hPa}$ wind vectors $\left(\mathrm{m} \mathrm{s}^{-1}\right),(\mathrm{c})$ precipitation $(\mathrm{mm}),(\mathrm{d}) 850-\mathrm{hPa}$ geopotential height $(\mathrm{m})$ and $850-\mathrm{hPa}$ wind vectors $\left(\mathrm{m} \mathrm{s}^{-1}\right)$, and (e) 500-hPa geopotential height $(\mathrm{m})$ and $500-\mathrm{hPa}$ wind vectors $\left(\mathrm{m} \mathrm{s}^{-1}\right)$. (f)-(j) As in (a)-(e), but for April-October. To get averages for all months, the 10 strongest and weakest LLJ years were first determined for each month and then averaged across all months considered (a set of 120 months for all months, 84 months for April-October).

PNA years, both for averages of all months and warmseason months (Fig. 5). In addition, enhanced rainfall around Hawaii and reduced precipitation off the west coast of North America in averages of strong minus weak LLJ years for all months (Fig. 2c) are nearly identical to anomalies during the negative phase of the PNA as reported by Yu et al. (2009) (also shown in Fig. 5c). Therefore, the difference in 500-hPa heights during strong and weak LLJ years (Fig. 2e) is likely related to the PNA and its associated North Pacific diabatic heating anomalies. Precipitation anomalies in the North Pacific are weaker during strong LLJ years in warm-season months (Fig. 2h) compared to averages of all months, but they closely resemble the precipitation differences between the most negative and positive PNA months in the warm season (Fig. 5f). This suggests that $500-\mathrm{hPa}$ height differences between strong and weak LLJ months during the warm season are also influenced by the PNA and related diabatic heating anomalies in the North Pacific. 

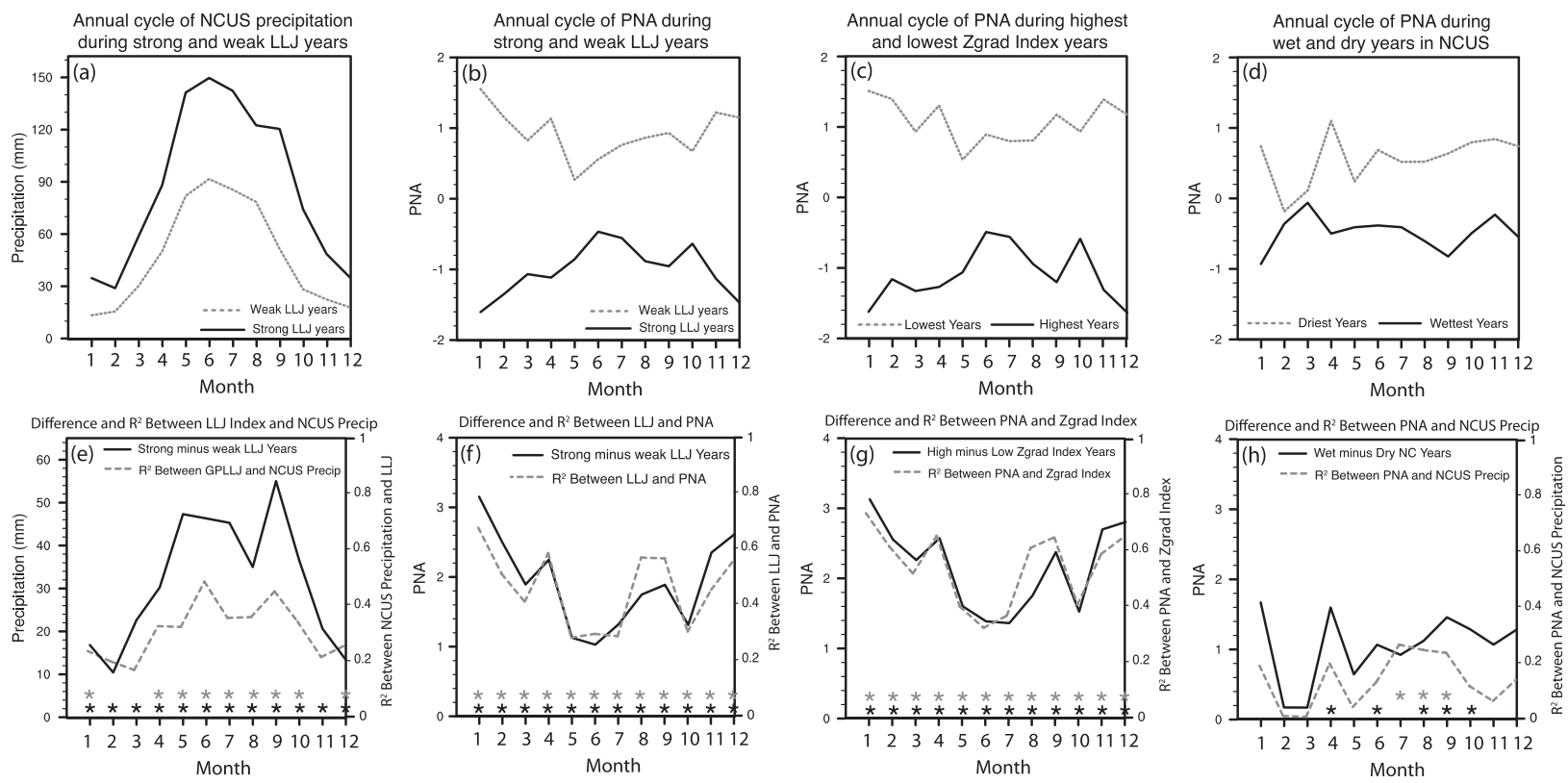

FIG. 3. Annual cycle of (a) NCUS CRU precipitation during the 1948-2013 period for the 10 strongest and weakest LLJ years (strongest and weakest determined for each month), (b) PNA during the 10 strongest and weakest LLJ years for each month, (c) PNA during the 10 highest and lowest Zgrad index years (for each month), and (d) PNA during 10 wettest and driest years (for each month) in NCUS. Also shown are the annual cycle of (e) precipitation difference between 10 strongest and weakest LLJ years and $R^{2}$ between LLJ index and NCUS precipitation, (f) PNA difference between 10 strongest and weakest LLJ years and $R^{2}$ between LLJ index and PNA, (g) PNA difference between 10 highest and lowest Zgrad index years and $R^{2}$ between PNA and Zgrad index, and (h) PNA difference between 10 wettest and driest years in NCUS and $R^{2}$ between PNA and NCUS precipitation. Asterisks indicate $95 \%$ confidence for differences (black) using a Student's $t$ test and for coefficients of determination $\left(R^{2}\right.$; gray) using an $F$ test.

For all months of the year, the PNA is negative during the strongest LLJ years and positive during the weakest LLJ years, with a statistically significant difference for all months (Figs. 3b,f). Overall, the PNA is responsible for $42 \%$ of the total variance in the GPLLJ on monthly time scales when considering all months (Fig. 4c), with a slightly weaker relationship (38.5\% of the variance explained) during the warm season (Fig. 4f). The PNA principally impacts the strength of the GPLLJ by affecting 850-hPa height differences between the Great Plains and SEUS, represented as the Zgrad index (section 2d). A significant percentage $(53 \%)$ of the monthly variance in the Zgrad index is related to the PNA when considering all months (Figs. 3c,g and 4b), with a slightly weaker relationship between the PNA and Zgrad index during the warm season ( $47 \%$; Fig. $4 \mathrm{e})$. As such, the PNA has the greatest effect on the Zgrad index during January (73\%) and the weakest in June (32\%) (Fig. 3g). These results indicate that the negative phase of the PNA enhances the GPLLJ by increasing the low-level pressure gradient within the GPLLJ core, which lies between two opposing "centers of action" of the PNA. When the PNA is negative, troughing over the Great Plains and ridging over the southeastern United States (on the western edge of the NASH) combine to enhance the height gradient within the GPLLJ core, while a positive PNA typically causes a weaker gradient by increasing heights over the Great Plains and lowering heights in the SEUS.

Despite the weaker influence of the PNA on lower and midtropospheric height patterns during the warm season, the PNA has significant warm season impacts on NCUS precipitation due to the greater effect of the LLJ on precipitation (Table 2). All months during the warm season (except May) exhibit either a statistically significant difference in the PNA between the wettest and driest years in the NCUS or a statistically significant (albeit small) coefficient of determination $\left(R^{2}\right)$ (Fig. 3h). Similarly, the strongest LLJ years (and the wettest years) in the warm season have a significantly more negative PNA than the weakest LLJ years (and driest years) (Fig. 3d, Table 2). These results suggest that while the PNA exerts much more variability during the winter, the PNA has enough warm-season influence on the LLJ to impact precipitation over the north central United States.

\section{Warm-season impact of the PNA on strong LLJ events and heavy precipitation events}

In the previous section, we demonstrated how the PNA could influence the GPLLJ by strengthening the 

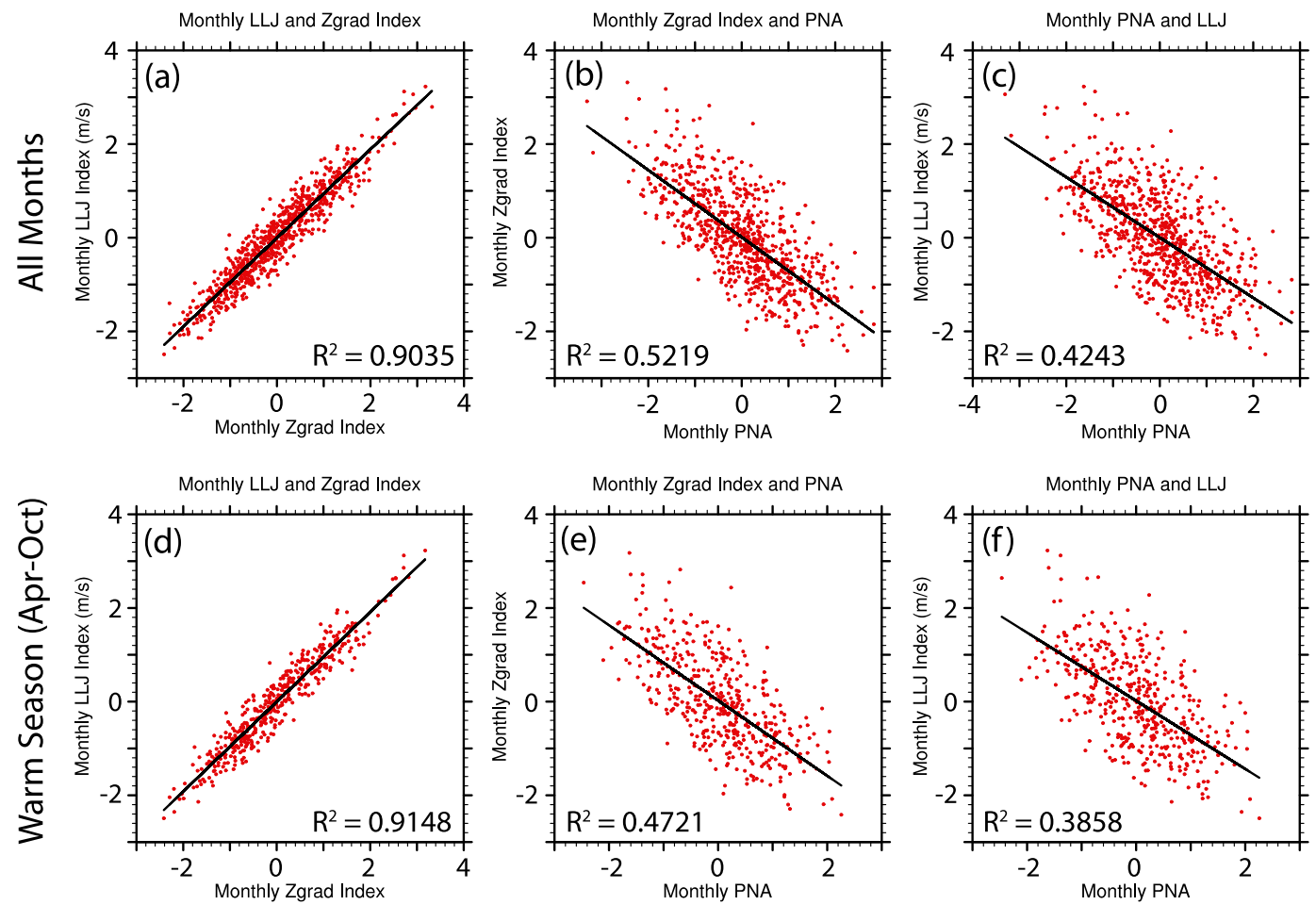

FIG. 4. For the period of 1948-2013, scatterplots for monthly (a) LLJ index and Zgrad index, (b) Zgrad index and PNA, and (c) PNA and LLJ index from NCEP-NCAR reanalysis for all months. (d)-(f) As in (a)-(c), but for the warm season (April-October).

850-hPa height gradient in the central United States during the warm season on monthly time scales. Here we use this knowledge to investigate how the PNA influences the GPLLJ and north central U.S. heavy precipitation events on time scales of five days (pentads) or less during the warm season (April-October).

Similar to the monthly results, geopotential height gradients within the GPLLJ core (represented as the Zgrad index) affect the strength of the GPLLJ on daily ( $81 \%$ of the explained variance) and 5-day ( $88 \%$ of the explained variance) time scales (Figs. 6a,d). The PNA, which can strengthen the 850 -hPa height gradient within the GPLLJ core during the negative phase of the PNA on monthly time scales, is responsible for a significant percentage of the daily $(27 \%)$ and pentadal $(33 \%)$ variability in the Zgrad index (Figs. 6b,e). Because the PNA can influence height gradients that control the strength of the GPLLJ, the PNA has a modest effect on the daily and pentadal variability of GPLLJ strength (19\% and $25 \%$ of the variance explained, respectively; Figs. 6c,f).

While the PNA has a significant impact on the GPLLJ at daily and pentadal time scales, heavy rainfall events over the north central United States are often associated with strong LLJ events that are typically less than $24 \mathrm{~h}$ in duration and can be heavily influenced by diurnal variations in GPLLJ strength. Using 6-hourly data from NCEP-NCAR, the PNA is predominantly negative and is much more likely to be very negative than very positive during times when a strong LLJ is present (Fig. 7). When no LLJ is present, the PNA is primarily positive and a large percentage of non-LLJ events are associated with positive or very positive PNA values (Fig. 7). However, a substantial number of strong LLJs (Fig. 7b) and discrete strong LLJ events (defined in section 2e) are associated with a positive ( $27.2 \%$ and $28.6 \%$, respectively) or very positive PNA (4.2\% and $5.4 \%$ ) (Table 3 ).

During strong LLJ events, an $850-\mathrm{hPa}$ trough is present over the Great Plains with anomalously high heights in the southeastern United States (Figs. 8a,b), as suggested by the strong relationship between the LLJ and Zgrad indices (Figs. 6a,d). These height anomalies occur regardless of whether the PNA is very negative or very positive (Figs. 8a,b). However, the wavelengths of troughs/ridges at $850 \mathrm{hPa}$ are much shorter in composites of strong LLJ events with a very positive PNA compared to events with a very negative PNA (Figs. $8 \mathrm{a}, \mathrm{b})$. The same wavelength disparity occurs at $500 \mathrm{hPa}$ for strong LLJ events associated with a very negative or very positive PNA (Figs. 8c,d). Using the Rossby wave speed equation (Rossby 1938; see the appendix), this implies that individual troughs and ridges 

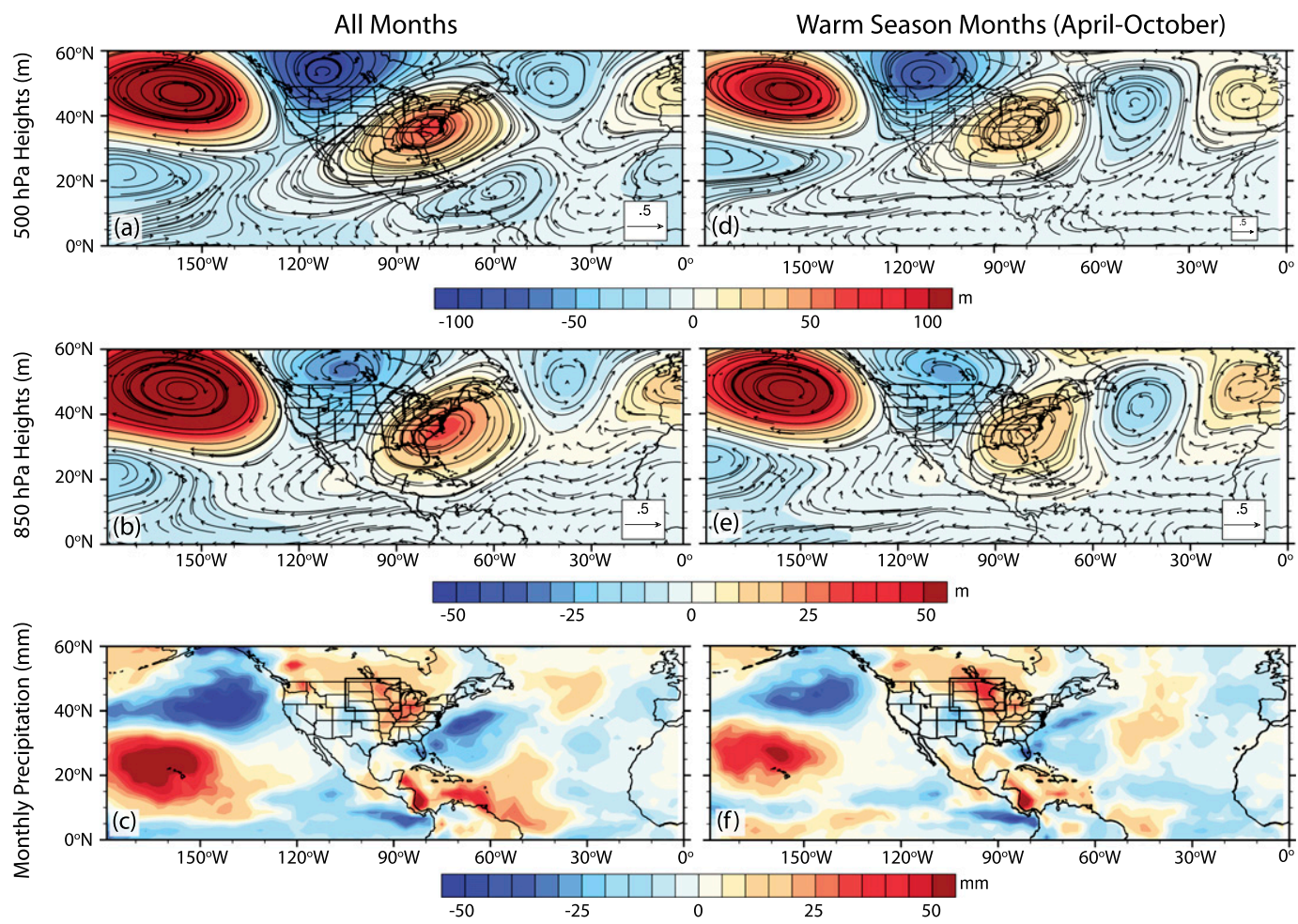

FIG. 5. The average over all calendar months during the 10 most negative minus the 10 most positive PNA years over the 1948-2013 period from NCEP-NCAR in (a) 500-hPa geopotential height (m) and 500-hPa wind vectors $\left(\mathrm{m} \mathrm{s}^{-1}\right)$, (b) 850-hPa geopotential height (m) and 850-hPa wind vectors $\left(\mathrm{m} \mathrm{s}^{-1}\right)$, and (c) NCEP-NCAR monthly precipitation $\left(\mathrm{mm} \mathrm{month}^{-1}\right)$. (d)-(f) As in (a)-(c), but for April-October. To get averages for all months, the 10 highest and lowest PNA years were first determined for each month and then averaged across all months considered (a set of 120 months for all months, 84 months for April-October).

propagate eastward faster during strong LLJ events when the PNA is very positive and upper-level flow features exhibit much shorter wavelengths. Therefore, the $850-\mathrm{hPa}$ height pattern that strengthens the height gradient across the GPLLJ core and favors the development of a strong LLJ is theoretically less persistent with a very positive PNA. Strong LLJ events are significantly longer in duration when associated with a very negative PNA compared to a very positive PNA (Table 3; $p<0.10$ ), suggesting that the trough/ridge wavelength disparity between LLJ events with a very negative/positive PNA may play a role in controlling the duration of strong LLJ events.

In addition, slightly more strong LLJ events associated with a very positive PNA $(45.2 \%)$ are only $6 \mathrm{~h}$ in duration and occur at either 0600 or 1200 UTC compared with very negative events (39.4\%). Many of these shortduration nocturnal LLJ events are likely an artifact of the inertial oscillation of the GPLLJ and the nocturnal decoupling of the boundary and surface layers that have been shown to cause the nocturnal maximum of the GPLLJ. This implies that some strong LLJ events with a very positive PNA may be more related to the inertial oscillation of the GPLLJ and nocturnal decoupling rather than a large-scale flow pattern that induces a persistent pressure gradient across the region and lingers longer than the time scale of a single weather system.

Strong LLJ events also exhibit stronger southerly flow in the LLJ region throughout the duration of events when the PNA is very negative (Table 3; Figs. 8e,f, vectors). The stronger and more persistent southerly flow enables greater moisture transport and precipitation to occur during strong LLJ events when the PNA is very negative versus very positive (Table 3; Figs. 8e,f). Because anomalously strong southerly flow and enhanced moisture transport persist longer when the PNA is negative or very negative, a significant majority of the greatest NCUS 5-day rainfall totals from individual grid cells in the CPC dataset are associated with a negative PNA (Table 4). Similarly, for the 100 greatest 5-day rainfall events based on regionally averaged precipitation, the PNA is predominantly negative $(76 \%)$ and many more events are associated with a very negative $(31 \%)$ rather than a very positive PNA (5\%). 

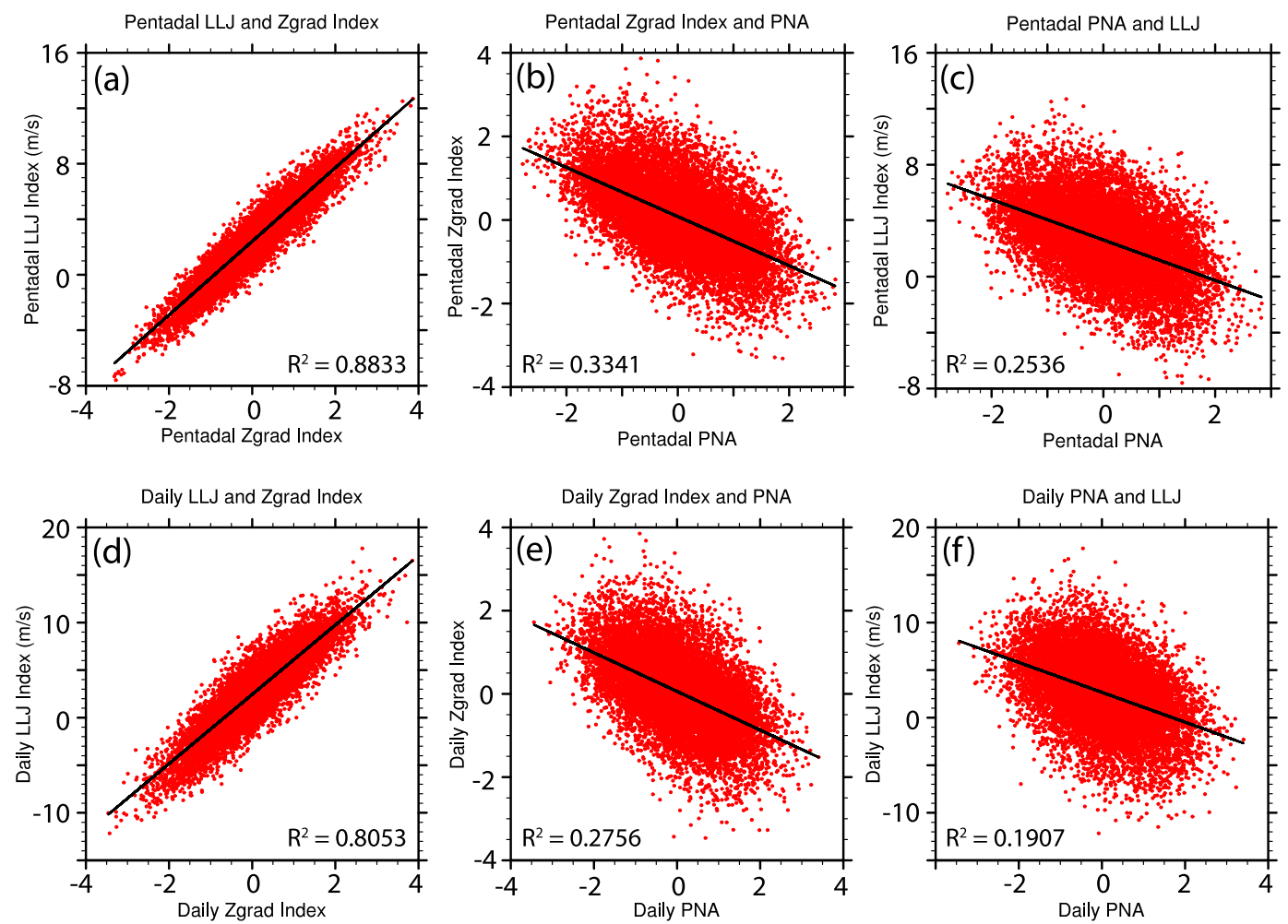

FIG. 6. For the period of 1948-2013, scatterplots of pentadal (a) LLJ index and Zgrad index, (b) Zgrad index and PNA, and (c) PNA and LLJ index from NCEP-NCAR reanalysis for April-October. (d)-(f) As in (a)-(c), but for daily values.

This suggests that the relationship between the PNA and NCUS heavy rainfall events is independent of the scale of event classification (grid cells versus regional averages). In addition, as grid cell event rainfall totals increase, the PNA becomes more negative and a greater share of heavy rainfall events occur during a negative or very negative PNA (Table 4; see Table S1 in the supplemental material). Of the 10 highest 5-day rainfall totals, nine are associated with a negative average PNA, while seven of them are very negative and none of them



(a)

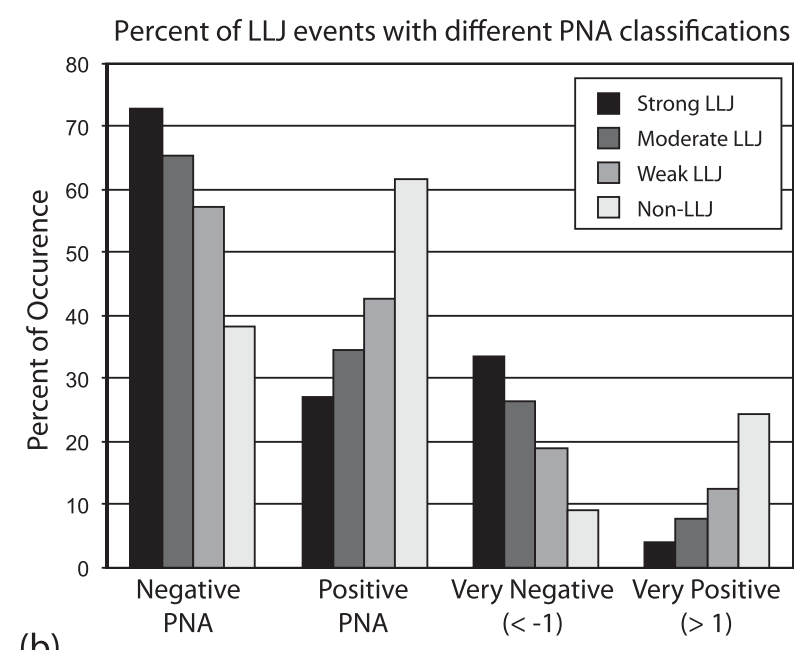

(b)
FIG. 7. (a) April-October average PNA for 6-h periods with a strong LLJ, moderate LLJ, weak LLJ, or no LLJ present for the period of 1948-2013 from the NCEP-NCAR reanalysis. (b) As in (a), but for the percent of each type of LLJ associated with a negative PNA, positive PNA, very negative PNA, and very positive PNA. 
TABLE 3. Duration, average meridional wind, total precipitation, maximum event total precipitation, and average moisture transport during strong LLJ events with different PNA classifications during April-October (95\% confidence intervals shown using standard error and Student's $t$ distribution).

\begin{tabular}{|c|c|c|c|c|c|c|}
\hline $\begin{array}{l}\text { PNA event } \\
\text { classification }\end{array}$ & $\begin{array}{l}\text { No. of events } \\
\text { (Percent of total } \\
\text { events) }\end{array}$ & $\begin{array}{c}\text { Duration of } \\
\text { event (h) }\end{array}$ & $\begin{array}{l}\text { Avg meridional } \\
\text { wind }\left(\mathrm{m} \mathrm{s}^{-1}\right)^{\mathrm{a}}\end{array}$ & $\begin{array}{l}\text { Total } \\
\text { precipitation } \\
(\mathrm{mm})^{\mathrm{b}}\end{array}$ & $\begin{array}{c}\text { Max event } \\
\text { rainfall }(\mathrm{mm})^{\mathrm{b}}\end{array}$ & $\begin{array}{c}\text { Avg moisture } \\
\text { transport } \\
\left(\mathrm{m} \mathrm{s}^{-1}\right)^{\mathrm{a}}\end{array}$ \\
\hline Very negative $(<-1)$ & $569(32.8 \%)$ & $17.03 \pm 1.29$ & $8.39 \pm 0.19$ & $14.38 \pm 1.72$ & 208.26 & $3.03 \pm 0.06$ \\
\hline Negative $(<0)$ & $1236(71.4 \%)$ & $17.72 \pm 0.94$ & $8.07 \pm 0.14$ & $15.04 \pm 1.22$ & 208.26 & $2.94 \pm 0.04$ \\
\hline Positive $(>0)$ & $496(28.6 \%)$ & $16.20 \pm 1.30$ & $6.94 \pm 0.30$ & $12.54 \pm 1.59$ & 116.19 & $2.64 \pm 0.06$ \\
\hline Very positive $(>1)$ & $93(5.4 \%)$ & $14.19 \pm 2.55$ & $5.62 \pm 0.88$ & $9.07 \pm 2.71$ & 89.60 & $2.57 \pm 0.12$ \\
\hline
\end{tabular}

${ }^{a}$ LLJ region used for calculation.

${ }^{b}$ North central region used for calculation.

is very positive. These results suggest that very heavy 5-day rainfall events in the north central United States are generally associated with the negative phase of the PNA, with a large number occurring when the PNA is very negative. Stronger southerly flow within the GPLLJ during heavy rainfall events with a very negative PNA increases the transport of moisture from the Gulf of Mexico compared to events with a very positive PNA (Table 5), reducing precipitation recycling ratios during those events (Table 5). Higher precipitation recycling ratios during heavy rainfall events with a very positive PNA suggest that increased locally derived moisture slightly offsets the reduced southerly transport of moisture associated with the very positive phase of the PNA. In this manner,
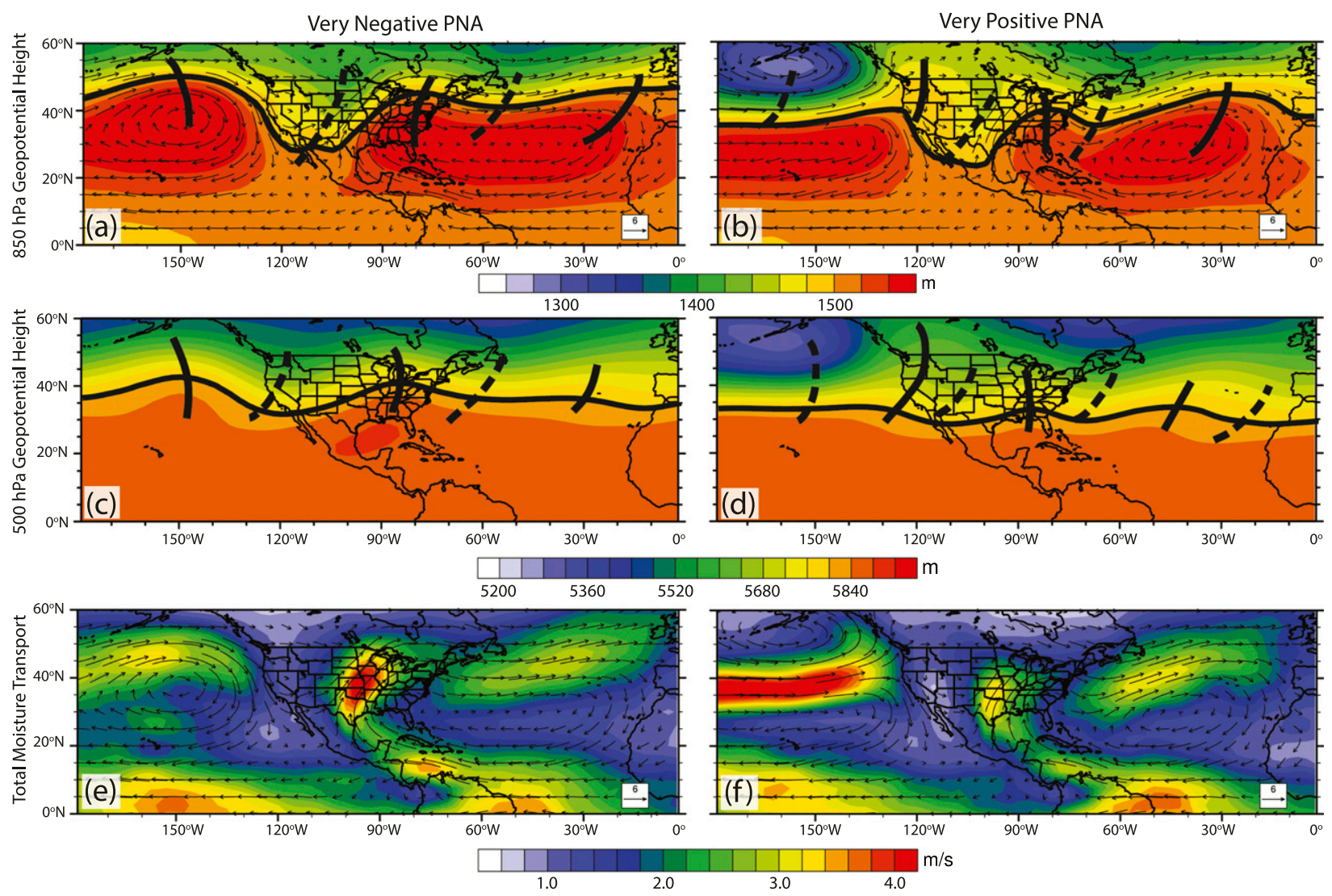

FIG. 8. (a) For the period of 1948-2013, 850-hPa geopotential height (m) and 850-hPa wind vectors ( $\mathrm{m} \mathrm{s}^{-1}$ ) during April-October strong LLJ events associated with a very negative PNA average during the LLJ event. (b) As in (a), but for a very positive PNA. (c),(d) As in (a),(b), but for 500-hPa geopotential height (m) and 500-hPa wind vectors ( $\mathrm{m} \mathrm{s}^{-1}$ ). (e),(f) As in (a),(b), but for the total vertically integrated moisture transport $\left(\mathrm{m} \mathrm{s}^{-1}\right)$ and average $850-\mathrm{hPa}$ wind vectors $\left(\mathrm{m} \mathrm{s}^{-1}\right)$ during the duration of strong LLJ events. In (a)-(d), ridges and troughs are denoted by thick solid and thick dashed lines, respectively, and the $1500-($ for $850 \mathrm{hPa}$ ) and $5840-\mathrm{m}$ (for $500 \mathrm{hPa}$ ) isoheights are thickened to highlight large-scale flow features. 
TABLE 4. Average PNA during the greatest 5-day precipitation events over the NCUS during April-October in the CPC dataset (19482013). Percent of the highest precipitation events associated with a very negative $(<-1)$, negative, positive, or very positive $(>1)$ average PNA during a 5-day precipitation event are also shown. The greatest 5-day precipitation events are determined by finding the highest 5-day rainfall for any grid cell within the north central region in the CPC dataset, with any overlapping events (temporally and spatially) excluded.

\begin{tabular}{|c|c|c|c|c|c|c|}
\hline $\begin{array}{l}\text { No. of events } \\
\text { considered }\end{array}$ & $\begin{array}{c}\text { Avg event } \\
\text { precipitation }(\mathrm{mm})\end{array}$ & Avg PNA & $\begin{array}{l}\text { Very negative } \\
\text { PNA avg }\end{array}$ & $\begin{array}{l}\text { Negative } \\
\text { PNA avg }\end{array}$ & $\begin{array}{l}\text { Positive } \\
\text { PNA avg }\end{array}$ & $\begin{array}{c}\text { Very positive } \\
\text { PNA avg }\end{array}$ \\
\hline 100 & 225.66 & -0.55 & $31 \%$ & $76 \%$ & $24 \%$ & $8 \%$ \\
\hline 50 & 247.40 & -0.60 & $36 \%$ & $78 \%$ & $22 \%$ & $8 \%$ \\
\hline 25 & 269.76 & -0.71 & $40 \%$ & $84 \%$ & $16 \%$ & $4 \%$ \\
\hline 10 & 295.52 & -1.17 & $70 \%$ & $90 \%$ & $10 \%$ & $0 \%$ \\
\hline
\end{tabular}

variations in land-atmosphere coupling might reduce the influence of the PNA on the development of heavy rainfall events by reducing the influence of advected moisture on the production of high rainfall totals.

Considering the evolution of the PNA before and after heavy rainfall events, the PNA is typically negative several days before the greatest 1-day heavy rainfall events over the north central United States, with an extended period of negative values $2-12$ days prior to the top 50 and top 100 events and the lowest value $1-2$ days before events (Fig. 9). Out of the top 100 heavy rainfall events, 79 have a very negative PNA within two weeks prior to events, much higher than the $57.8 \%$ of all 14-day periods within the entire NCEP-NCAR reanalysis that have a very negative PNA. Additionally, 10000 Monte Carlo simulations comprising 100 randomized 14-day periods indicate only a $0.001 \%$ probability ( 4.25 standard deviations from the mean) that 79 out of 100 randomly selected 14-day periods would have a very negative PNA by random chance. While a large percentage of heavy rainfall events are associated with the negative or very negative phase of the PNA, a significant portion of summer (June-August) days with very negative PNA values are also coincident with heavy rainfall events. In 1948-2013, $34.3 \%$ of all summer days with a PNA $\leq-2$ (102 days) and $25.0 \%$ of summer days with a PNA $\leq-1$ (930 days) have a 3 -in. rainfall event $(1 \mathrm{in} . \approx 25.4 \mathrm{~mm})$ within the NCUS, compared to just $6.6 \%$ of summer days with a PNA $\geq 2$ (121 days) and $10.0 \%$ of summer days with a PNA $\geq 1$ (1006 days). These results suggest that the very negative phase of the PNA has a significant influence on the development of heavy rainfall events over the north central United States by strengthening the GPLLJ and enhancing moisture transport into the region.

\section{Conclusions}

In this study, we use the NCEP-NCAR reanalysis to demonstrate that the PNA can affect the strength of the GPLLJ on 6-hourly to monthly intervals, with a greater impact at longer time scales. Contrasting low-level height anomalies associated with two PNA "centers of action" occur on opposite sides of the GPLLJ core and modify the pressure gradient within the GPLLJ, influencing the strength of the GPLLJ. The negative phase of the PNA is shown to enhance the GPLLJ, which increases moisture transport within the GPLLJ and precipitation in the north central United States. We find that the PNA has a modest impact on warm season north central United States precipitation on monthly time scales despite decreased variability in the PNA during the warm season. Similarly, because the negative phase of the PNA enhances the GPLLJ on 6-hourly to pentadal time scales, a large majority of heavy rainfall events within the north central United States are associated with the negative phase of the PNA.

Strong LLJ events are predominantly associated with the negative phase of the PNA, with non-LLJ events mostly occurring when the PNA is positive. While strong LLJ events can occur with a positive or very positive PNA, the shorter wavelength features that are present in the upper-level flow pattern during strong LLJ events with a very positive PNA tend to be less persistent. In addition, strong LLJ events associated with a very

TABLE 5. Total precipitation ( $\mathrm{mm}$ ), average meridional wind in GPLLJ region, average moisture transport in GPLLJ region, and recycling ratio in the NCUS during top 100 5-day heavy rainfall events during April-October in CPC dataset. Confidence intervals of $95 \%$ shown using standard error and Student's $t$ distribution.

\begin{tabular}{lccrr}
\hline \hline & Avg event precipitation $(\mathrm{mm})$ & Avg LLJ $\left(\mathrm{m} \mathrm{s}^{-1}\right)$ & ${\text { Moisture transport }\left(\mathrm{m} \mathrm{s}^{-1}\right)}^{\text {Recycling ratio }}$ \\
\hline Very negative (31) & $234.82 \pm 13.64$ & $5.63 \pm 0.60$ & $2.89 \pm 0.28$ & $10.48 \pm 1.67 \%$ \\
Very positive (8) & $218.86 \pm 12.82$ & $4.43 \pm 1.62$ & $2.41 \pm 0.36$ & $13.85 \pm 3.07 \%$ \\
\hline
\end{tabular}




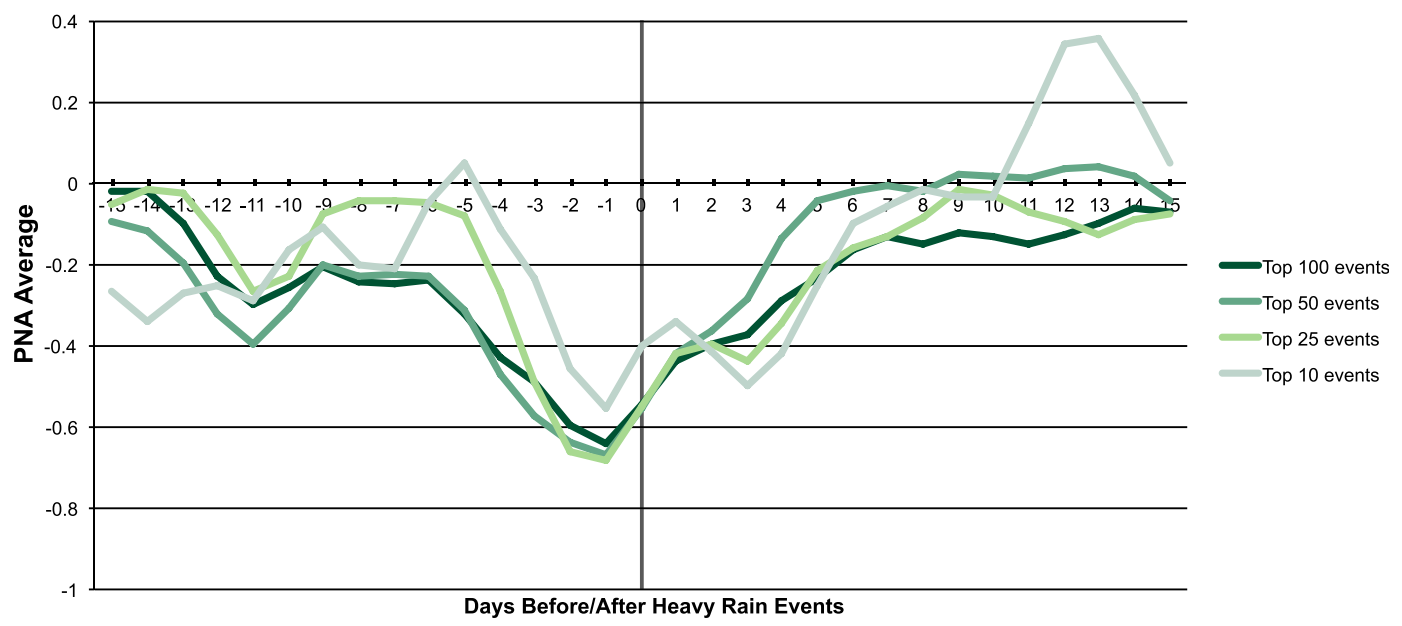

FIG. 9. Average PNA before and after top 10, top 25, top 50, and top 100 NCUS 1-day heavy rainfall events in April-October.

positive PNA are also more likely to be a by-product of the nocturnal maximum of the GPLLJ, resulting in shorter LLJ events when the PNA is very positive. Conversely, when the PNA is negative, the Rossby wave train induced by the PNA enables stronger and more sustained southerly flow within the GPLLJ. This supports more persistent moisture transport into the north central United States from the Gulf of Mexico, which can result in the production of heavy precipitation over several days and a greater possibility of flash flooding than from strong GPLLJ events with a very positive PNA. Conversely, heavy rainfall events in the north central United States with a very positive PNA typically have slightly more influence from locally derived precipitation compared to events with a very negative PNA. This demonstrates that heavy rainfall events are still possible when the PNA is positive, but the occurrence of heavy rainfall events with a very positive PNA may be more influenced by land-atmosphere interactions than times with a very negative PNA. Therefore, land-atmosphere interactions (e.g., precipitation recycling from evapotranspiration) could reduce the impact of the PNA on heavy rainfall events during times with enhanced land-atmosphere coupling. However, further study is needed to determine how land-atmosphere coupling may modulate the impact of the PNA on heavy rainfall events in the region.

The large societal and economic cost of flash flooding in the midwestern United States places greater importance on improving medium-range forecasting of heavy rainfall events. In this study, we show that very heavy rainfall events in the region are associated with the negative phase of the PNA through a prolonged enhancement of the GPLLJ. Recent work has demonstrated promising medium-range forecasting skill for the prediction of atmospheric rivers in the central United
States (Nayak et al. 2014), which are associated with anomalous meridional moisture transport within the GPLLJ (Lavers and Villarini 2013). The PNA has significant variability within this forecasting window and is typically very negative within two weeks prior to north central U.S. heavy rainfall events, with a significant percentage of extremely negative PNA events $(\leq-2)$ associated with heavy rain events. This suggests that improved medium-range prediction of the PNA might enable better prediction of destructive heavy rainfall events within the region. Understanding the relationship between the PNA and GPLLJ events could improve forecast lead times with the goal of minimizing socioeconomic losses from flash flooding in the region.

Acknowledgments. Support for this study was provided by the U.S. National Science Foundation under Grant 1029711. All data used in this study were downloaded from the NOAA/ESRL Physical Sciences Division website (http://www.esrl.noaa.gov/psd/data/gridded/). All other data and programs used to replicate the results in this study are available upon request from the corresponding author at pksnyder@umn.edu. We thank Dr. Christina Patricola and two anonymous reviewers for their constructive and thoughtful suggestions.

\section{APPENDIX}

\section{Rossby Wave Speed Equation}

The zonal phase speed $c$ of a Rossby wave relative to the mean flow $\bar{u}$ is

$$
c-\bar{u}=\frac{-\beta}{K^{2}}
$$


where $\beta$ is the change in the Coriolis force $f$ with latitude $(d f / d y)$ using the midlatitude $\beta$-plane approximation and $K$ is the horizontal wavenumber $(K=2 \pi / \lambda$, where $\lambda$ is the zonal wavelength) (Holton 2004; Rossby 1938). Equation (A1) implies that as the zonal wavelength decreases, Rossby waves propagate faster to the east (i.e., move more slowly westward relative to the mean flow).

\section{REFERENCES}

Arritt, R. W., T. D. Rink, M. Segal, D. P. Todey, C. A. Clark, M. J. Mitchell, and K. M. Labas, 1997: The Great Plains low-level jet during the warm season of 1993. Mon. Wea. Rev., 125, 2176-2192, doi:10.1175/1520-0493(1997)125<2176: TGPLLJ $>2.0 . \mathrm{CO} ; 2$.

Barnston, A. G., and R. E. Livezey, 1987: Classification, seasonality and persistence of low-frequency atmospheric circulation patterns. Mon. Wea. Rev., 115, 1083-1126, doi:10.1175 1520-0493(1987)115<1083:CSAPOL > 2.0.CO;2.

Bonner, W. D., 1968: Climatology of the low level jet. Mon. Wea. Rev., 96, 833-850, doi:10.1175/1520-0493(1968)096<0833. COTLLJ $>2.0 . \mathrm{CO} ; 2$.

Brubaker, K. L., P. A. Dirmeyer, A. Sudradjat, B. S. Levy, and F. Bernal, 2001: A 36-yr climatological description of the evaporative sources of warm-season precipitation in the Mississippi River basin. J. Hydrometeor., 2, 537-557, doi:10.1175/ 1525-7541(2001)002<0537:AYCDOT >2.0.CO;2.

Cook, K. H., E. K. Vizy, Z. S. Launer, and C. M. Patricola, 2008: Springtime intensification of the Great Plains low-level jet and Midwest precipitation in GCM simulations of the twenty-first century. J. Climate, 21, 6321-6340, doi:10.1175/ 2008JCLI2355.1.

CPC, 2014: Teleconnections: Pacific/North American pattern: Monthly mean PNA index. NWS Climate Prediction Center. Accessed 1 June 2014. [Available online at http://www.cpc.ncep.noaa.gov/ products/precip/CWlink/pna/month_pna_index2.shtml.]

Dirmeyer, P. A., and J. L. Kinter, 2010: Floods over the U.S Midwest: A regional water cycle perspective. J. Hydrometeor., 11, 1172-1181, doi:10.1175/2010JHM1196.1.

Dominguez, F., P. Kumar, X.-Z. Liang, and M. Ting, 2006: Impact of atmospheric moisture storage on precipitation recycling. J. Climate, 19, 1513-1530, doi:10.1175/JCLI3691.1.

Feldstein, S. B., 2000: The timescale, power spectra, and climate noise properties of teleconnection patterns. J. Climate, 13, 4430-4440, doi:10.1175/1520-0442(2000)013<4430:TTPSAC $>2.0$. CO;2.

Harris, I., P. D. Jones, T. J. Osborn, and D. H. Lister, 2014: Updated high-resolution grids of monthly climatic observations-The CRU TS3.10 dataset. Int. J. Climatol., 34, 623-642, doi:10.1002/joc.3711.

Helfand, H. M., and S. D. Schubert, 1995: Climatology of the simulated Great Plains low-level jet and its contribution to the continental moisture budget of the United States. J. Climate, 8, 784-806, doi:10.1175/1520-0442(1995)008<0784 COTSGP $>2.0 . \mathrm{CO} ; 2$

Higgins, R. W., Y. Yao, E. S. Yarosh, J. E. Janowiak, and K. C. Mo, 1997: Influence of the Great Plains low-level jet on summertime precipitation and moisture transport over the central United States. J. Climate, 10, 481-507, doi:10.1175/1520-0442(1997)010<0481: IOTGPL $>2.0 . \mathrm{CO} ; 2$.

_ - W. Shi, E. Yarosh, and R. Joyce, 2000: Improved United States precipitation quality control system and analysis NCEP/Climate Prediction Center Atlas 7, 40 pp. [Available online at http://www.cpc.ncep.noaa.gov/research_papers/ ncep_cpc_atlas/7/index.html.]

Holton, J. R., 1967: The diurnal boundary layer wind oscillation above sloping terrain. Tellus, 19A, 199-205, doi:10.1111/ j.2153-3490.1967.tb01473.x.

2004: An Introduction to Dynamic Meteorology. 4th ed. Elsevier Academic, 535 pp.

Kalnay, E., and Coauthors, 1996: The NCEP/NCAR 40-Year Reanalysis Project. Bull. Amer. Meteor. Soc., 77, 437-471, doi:10.1175/ 1520-0477(1996)077<0437:TNYRP $>2.0$. CO;2.

Lau, K. M., and J. S. Boyle, 1987: Tropical and extratropical forcing of the large-scale circulation-A diagnostic study. Mon. Wea. Rev., 115, 400-428, doi:10.1175/1520-0493(1987)115<0400: TAEFOT $>2.0 . \mathrm{CO} ; 2$.

Lavers, D. A., and G. Villarini, 2013: Atmospheric rivers and flooding over the central United States. J. Climate, 26, 78297836, doi:10.1175/JCLI-D-13-00212.1.

Leathers, D. J., and M. A. Palecki, 1992: The Pacific/North American teleconnection pattern and United States climate. Part II: Temporal characteristics and index specification. J. Climate, 5, 707-716, doi:10.1175/1520-0442(1992)005<0707: TPATPA $>2.0 . \mathrm{CO} ; 2$.

Means, L. L., 1954: A study of the mean southerly wind-Maximum in low levels associated with a period of summer precipitation in the Middle West. Bull. Amer. Meteor. Soc., 35, 166-170.

Merrill, J. T., R. Bleck, and D. Boudra, 1986: Techniques of Lagrangian trajectory analysis in isentropic coordinates. Mon. Wea. Rev., 114, 571-581, doi:10.1175/1520-0493(1986)114<0571: TOLTAI $>2.0 . \mathrm{CO} ; 2$.

Mo, K. C., and E. H. Berbery, 2004: Low-level jets and the summer precipitation regimes over North America. J. Geophys. Res., 109, D06117, doi:10.1029/2003JD004106.

Monaghan, A. J., D. L. Rife, J. O. Pinto, C. A. Davis, and J. R. Hannan, 2010: Global precipitation extremes associated with diurnally varying low-level jets. J. Climate, 23, 5065-5084, doi:10.1175/2010JCLI3515.1.

Nayak, M. A., G. Villarini, and D. A. Lavers, 2014: On the skill of numerical weather prediction models to forecast atmospheric rivers over the central United States. Geophys. Res. Lett., 41, 4354-4362, doi:10.1002/2014GL060299.

NWS, 2014: Natural hazard statistics. Accessed 29 May 2014. [Available online at http://www.nws.noaa.gov/om/hazstats.shtml.]

Patricola, C. M., P. Chang, and R. Saravanan, 2015: Impact of Atlantic SST and high frequency atmospheric variability on the 1993 and 2008 Midwest floods: Regional climate model simulations of extreme climate events. Climatic Change, 129, 397-411, doi:10.1007/s10584-013-0886-1.

Rasmusson, E. M., 1968: Atmospheric water vapor transport and the water balance of North America. II: Large-scale water balance investigations. Mon. Wea. Rev., 96, 720-734, doi:10.1175/ 1520-0493(1968)096<0720:AWVTAT >2.0.CO;2.

Rossby, C. G., 1938: On the mutual adjustment of pressure and velocity distributions in certain simple current systems. II. J. Mar. Res., 1, 239-263.

Trenberth, K. E., G. W. Branstator, D. Karoly, A. Kumar, N. C. Lau, and C. Ropelewski, 1998: Progress during TOGA in understanding and modeling global teleconnections associated with tropical sea surface temperatures. J. Geophys. Res., 103 (C7), 14 291-14 324, doi:10.1029/97JC01444.

Wallace, J. M., and D. S. Gutzler, 1981: Teleconnections in the geopotential height field during the Northern Hemisphere winter. Mon. Wea. Rev., 109, 784-812, doi:10.1175/ 1520-0493(1981)109<0784:TITGHF>2.0.CO;2. 
Weaver, S. J., and S. Nigam, 2008: Variability of the Great Plains low-level jet: Large-scale circulation context and hydroclimate impacts. J. Climate, 21, 1532-1551, doi:10.1175/ 2007JCLI1586.1.

_, and _ 2011: Recurrent supersynoptic evolution of the Great Plains low-level jet. J. Climate, 24, 575-582, doi:10.1175/ 2010JCLI3445.1.

_- A. Ruiz-Barradas, and S. Nigam, 2009a: Pentad evolution of the 1988 drought and 1993 flood over the Great Plains: An NARR perspective on the atmospheric and terrestrial water balance. J. Climate, 22, 5366-5384, doi:10.1175/ 2009JCLI2684.1.

, S. Schubert, and H. Wang, 2009b: Warm season variations in the low-level circulation and precipitation over the central United States in observations, AMIP simulations, and idealized SST experiments. J. Climate, 22, 5401-5420, doi:10.1175/ 2009JCLI2984.1.

Yu, B., Y. M. Tang, X. B. Zhang, and A. Niitsoo, 2009: An analysis on observed and simulated PNA associated atmospheric diabatic heating. Climate Dyn., 33, 75-91, doi:10.1007/s00382-008-0432-4. 